JURNAL RISET REKAYASA ELEKTRO

Vol.2, No.2, Desember 2020, Hal. 85 93

P-ISSN: 2685 - $4341 \quad$ E-ISSN: 2685 - 5313

\title{
Rancang Bangun Pengatur Infus Berbasis Mikrokontroller
}

\author{
Mahendra Bagaskara ${ }^{1}$, Wakhyu Dwiono ${ }^{2}$,Latiful Hayat ${ }^{3}$ \\ Program Studi S1 Teknik Elektro, Universitas Muhammadiyah Purwokerto \\ Fakultas Teknik dan Sains, Universitas Muhammadiyah Purwokerto
}

\section{Informasi Makalah}

Dikirim, 22 Agustus 2020

Direvisi, 24 Desember 2020

Diterima, 29 Desember 2020

\section{Kata Kunci:}

Pengatur Tetesan Infus Mikrokontroler IoT

\section{Keyword:}

Infusion Drop Control

Microcontroller

IoT

\section{INTISARI}

Dalam dunia medis infus merupakan alat yang paling sering digunakan, fungsi infus sendiri yaitu untuk memberikan cairan kepada pasien secara berkala. Kesalahan dalam pemberian cairan infus dapat berakibat buruk kepada pasien, juga apabila terjadi masalah seperti penyumbatan atau kehabisan cairan jika tidak segera ditangani akan berbahaya bagi pasien. Infus yang ada saat ini penggunaannya masih secara manual dimana kesalahan - kesalahan seperti tersebut masih sering terjadi, oleh karena itu dalam penelitian ini membuat infus yang dapat bekerja secara otomatis serta dipantau dari jarak jauh. Pada penelitian ini membuat pengatur infus berbasis mikrokontroller yang dapat di monitoring secara berkala menggunakan handphone yang sistem kerjanya seperti Internet of Thing karena dalam memonitoring perangkat dan aplikasi android tersambung dengan internet, serta dapat diatur menggunakan button yang berguna untuk memasukan jumlah tetesan infus. Sensor yang digunakan pada alat ini infrared transmitter dan infrared receiver berdiameter $5 \mathrm{~mm}$ dan untuk pendeteksi detak jantung menggunakan MAX30100 sebagai feedback dari pasien. Sedangkan sebagai penekan selang menggunakan motor stepper $28 \mathrm{byj}-48$ dengan konfigurasi half-step. Mikrokontroller menggunakan ESP8266 sebagai kontrol motor servo serta mengirim data ke cloud. Oled 9,6" dan Button digunakan sebagai interface. Hasil yang didapat dari pengujian untuk mengatur jumlah tetesan infus tiap menit memiliki tingkat total rata - rata error $5,59 \%$. Sedangkan hasil pengujian untuk pendeteksian detak jantung memiliki nilai total rata - rata error $5,57 \%$ dan memiliki rata-rata delay dalam pengiriman maupun penerimaan data sebesar 59,6 microsecond.

\begin{abstract}
in the medical area, an infusion is the most often used tool. The function of this is to provide fluids to the patients regularly. Mistakes in administering intravenous fluids can harm the patient, such as blockages or dehydration. If it is untreated immediately, it will be dangerous for the patient. Recently, the infusion is still manually used so that the above errors may occur. Therefore, this study offers a solution in which an infusion can work automatically and can be monitored remotely. A microcontroller-based infusion can be monitored regularly using a cellphone whose system works like the Internet of Thing because in monitoring devices and android applications it is connected to the internet, and adjusted using a button to control the number of infusion drops. The sensors used in this tool were infrared transmitter and infrared receiver in 5mm diameter and MAX30100 as feedback from patients for heart rate detection. Meanwhile, for the hose pressure, $28 \mathrm{byj}-48$ stepper motor with a half-step configuration. The microcontroller is equipped with ESP8266 as a servo motor control and sent data to the cloud. Oled 9.6 and Button were selected as the interfaces. The test results for adjusting the number of infusion drops per minute an average total error rate of $5.59 \%$. Meanwhile, the test results for heart rate detection presented an average total error value of $5.57 \%$ and has an average delay in sending and receiving data of 59.6 microseconds.
\end{abstract}




\section{Korespondensi Penulis:}

Mahendra Bagaskara

Program Studi Teknik Elektro

Fakultas Teknik dan Sains Universitas Muhammadiyah Purwokerto

JL. Raya Dukuhwaluh, Purwokerto, 53182

Email: mahenbgskr@emailme.my.id

\section{PENDAHULUAN}

Perkembangan ilmu kedokteran dan teknologi yang semakin canggih menyebabkan tuntutan akan kemudahan. Kesalahan dalam pemberian cairan infus dapat berakibat buruk kepada pasien. Saat ini penggunaan infus di rumah sakit masih secara manual dimana kesalahan dalam pemberian cairan infus masih sering terjadi. Peran perawat dalam terapi infus terutama melakukan tugas delegasi. Bahwa pemberian terapi infus diinstruksikan oleh dokter tetapi perawat yang bertanggung jawab pada pemberian serta mempertahankan terapi tersebut pada pasien. Oleh karena itu, dalam melakukan tugasnya tersebut, perawat harus memiliki pengetahuan yang berkaitan dengan pengkajian, perencanaan, implementasi, dan evaluasi dalam perawatan terapi infus [1]. Perawat harus memiliki komitmen dalam memberikan terapi infus yang aman, efektif dalam pembiayaan, serta melakukan perawatan infus yang berkualitas [2]. Aliran yang akurat sangat penting untuk pemberian cairan dan obat yang tepat dan untuk keselamatan pasien dan harus dipertahankan ketika perangkat infus terpapar berbagai kondisi klinis [3]. Berbagai perangkat infus telah diperkenalkan untuk pemberian cairan intravena. Meskipun pengendali dropcounting yang diberi makan gravitasi telah digunakan secara luas untuk infus cairan, keakuratannya tidak optimal [4]. Pompa infus memberikan cairan, obat atau nutrisi ke dalam sistem sirkulasi pasien. Ini umumnya digunakan secara intravena, meskipun infus, arteri dan epidural kadang-kadang digunakan. Pompa infus dapat mengatur cairan dengan cara yang praktis tetapi relatif lebih mahal atau tidak dapat diandalkan jika dilakukan secara manual oleh staf perawat [5].

Sistem monitoring infus pernah merealisasikan alat monitoring infus menggunakan metode pendeteksian cairan infus dari berat infus yang dihubungkan dengan sebuah pegas. Alat ini mempunyai resolusi yang kecil karena sistem ini menggunakan metode perubahan resistansi dari potensiometer geser. Selain itu mekanik alat ini cukup sulit dan mempunyai ketahanan yang kurang baik karena infus dideteksi dari berat botol infus dengan menggunakan pegas dan potensiometer geser [6].

Perawat harus memiliki pengetahuan yang berkaitan dengan pengkajian, perencanaan, implementasi, dan evaluasi dalam perawatan terapi infus. Perawat harus memiliki komitmen dalam memberikan terapi infus yang aman, efektif dalam pembiayaan, serta melakukan perawatan infus yang berkualitas [7]. Kebutuhan cairan dan elektrolit merupakan kebutuhan dasar yang dibutuhkan untuk metabolisme tubuh. Beberapa sistem organ di dalam tubuh yang membantu dalam proses pemenuhannya, diantaranya yaitu ginjal, kulit, paru serta gastrointestinal [8]. Kekurangan volume cairan (FVD) merupakan ketidakseimbangan yang ditandai dengan defisiensi cairan dan elektrolit di ruang ekstraselular, tetapi proporsi antara keduanya (cairan dan elektrolit) mendekati normal, hipovolume dikenal juga dengan dehidrasi atau hypovolemia [9]

Berdasarkan latar belakang dan hasil penelitian di atas maka dibuat alat "Rancang Bangun Pengatur Infus Berbasis Mikrokontroller” yang dilengkapi sensor detak jantung sebagai feedback dari pasien, sensor tetesan untuk mendeteksi banyaknya tetesan yang terukur dan motor stepper untuk mengatur laju dari tetesan infus serta dibuat aplikasi android yang berguna untuk mempermudah dalam memonitoring detak jantung, tetesan, perkiraan infus habis, baterai alat, dan mengatur tetesan infus secara jarak jauh.

\section{METODE PENELITIAN}

\subsection{Flowchart Sistem}

Perancangan alat dapat bekerja dengan semestinya tentunya dibutuhkan diagram alir cara kerja perangkat, perangkat ini menggunakan ESP8266 sebagai mikrokontroler pada dengan memiliki tiga bagian utama karena pada digram alir ini ketiga program ini berjalan secara bergantian, pada bagian pertama adalah pembacaan sensor yang bekerja dalam rentang waktu setiap satu microsecond untuk mengupdate data yang didapat dari sensor detak jantung, Pada bagian kedua yaitu untuk mensetting tetesan yang akan menggendalikan motor stepper. Pada bagian ketiga yaitu saat menerima data set yang dikirim dari aplikasi 
android jika data yang diterima tidak sama dengan nilai set yang sudah ada maka akan mengeksekusi perintah pada bagian kedua.Diagram alir dari sistem dapat dilihat pada Gambar 1.

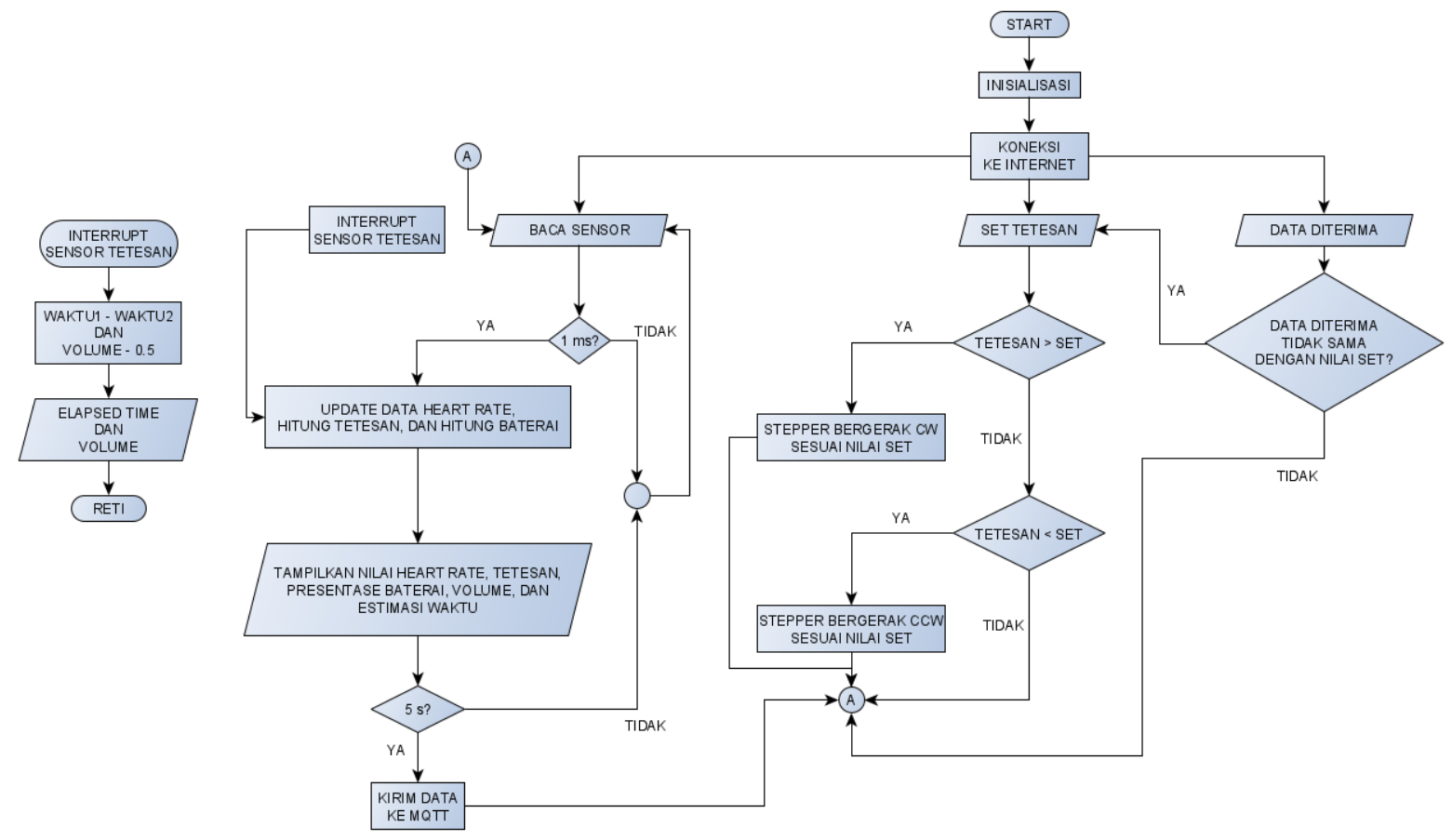

Gambar 1. Flowchart Sistem Alat

\subsection{Flowchart Aplikasi Android}

Adapula untuk perancangan aplikasi android, aplikasi ini berguna untuk memonitoring dan juga berfungsi untuk mengatur jumlah tetesan infus. Perancangan aplikasi android seperti Gambar 2 berikut.

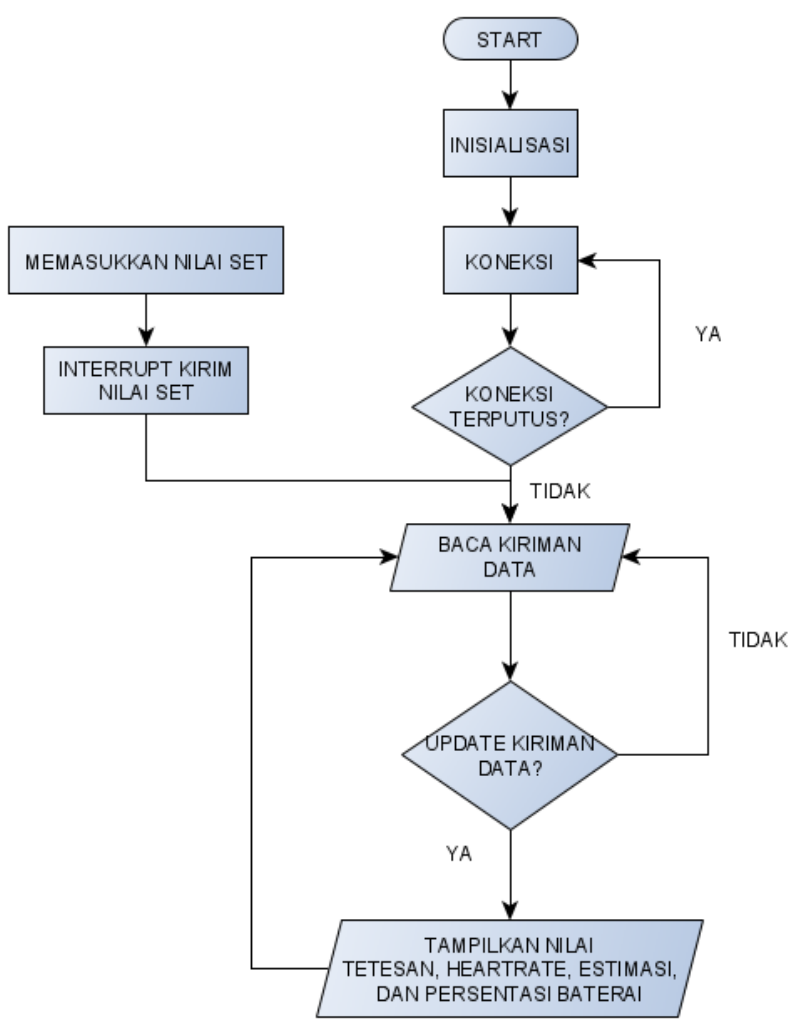

Gambar 2. Flowchart Aplikasi Android 


\subsection{Metode Sistem Yang Digunakan}

Untuk mengatur tetesan infus agar sesuai dengan jumlah tetesan yang diinginkan, untuk melipat selang motor stepper diatur jumlah stepper sesuai dengan sample tetesan yang diinginkan. Seperti Tabel 1 berikut.

Tabel 1. Nilai Step Berdasarkan Sample Tetesan

\begin{tabular}{cc}
\hline Sample Tetesan & Step \\
\hline 10 & 361 \\
20 & 375 \\
30 & 384 \\
40 & 394 \\
50 & 404 \\
60 & 414 \\
70 & 427 \\
80 & 437 \\
90 & 449 \\
100 & 461 \\
\hline
\end{tabular}

Metode untuk melipat selang yang berguna untuk mengatur jumlah tetesan pada infus dapat diilustrasikan pada gambar 3 berikut.
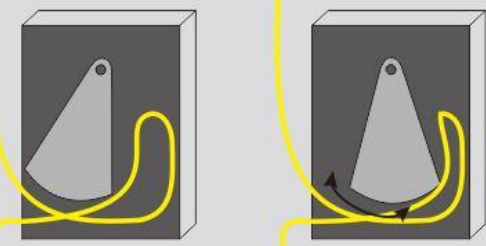

Gambar 3 Ilustrasi Pengatur Tetesan Infus

Gambar 3 merupakan ilustrasi dalam mengatur tetesan per menit yang cara kerjanya adalah penggerak akan bergeser kiri atau kanan sesuai dengan nilai step yang sudah di atur seperti Tabel 1 .

\subsection{Perancangan Perangkat Keras}

Box perangkat berfungsi untuk merapikan setiap komponen pada Alat dan tempat untuk sensor tetesan di desain dengan rapi untuk mempermudah meletakkan sensor pada drip chamber. Seperti Gambar 4 dan Gambar 5 berikut.
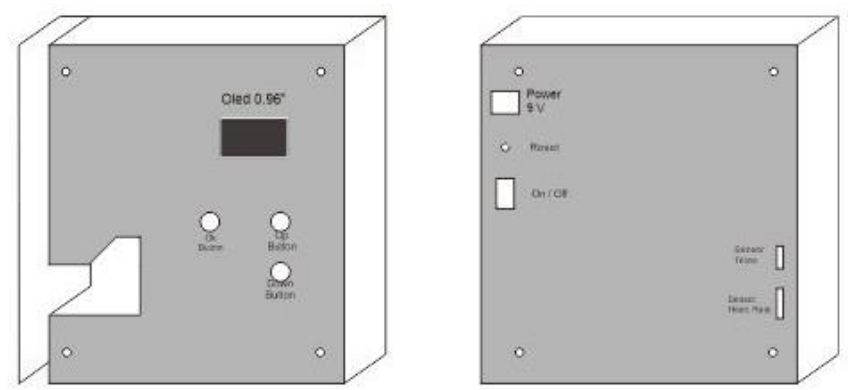

Gambar 4. Desain Box Alat Tampak Depan dan Belakang 


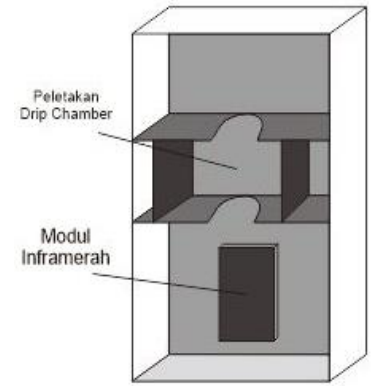

Gambar 5. Desain Tempat Sensor Tetesan

\subsection{Pengujian Gelombang Sensor Tetesan}

Pengujian sensor tetesan dilakukan dengan cara mendeteksi betuk gelombang yang terdeteksi dari aplikasi Logic seperti Gambar 6 berikut.

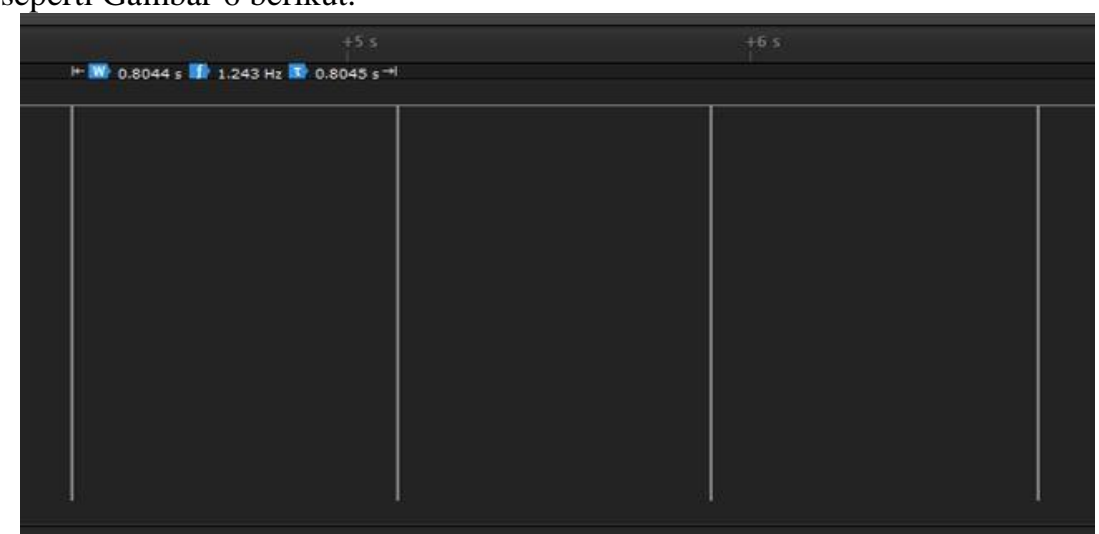

Gambar 6. Bentuk Gelombang Sensor Tetesan

Pada pengujian gelombang sensor tetesan, rentang waktu antara tetesan pertama dan kedua adalah 0,8044 detik dengan nilai volume $0,05 \mathrm{ml}$ karena setiap 1 tetes memiliki ukuran 0,05 $\mathrm{ml}$ dan faktor tetes 20, maka untuk mengetahui berapa jumlah tetesan per menit dapat dimasukkan dengan rumus berikut.

Tetesan Per Menit (TPM) $=\frac{\text { Volume } \mathrm{x} \text { Faktor Tetes }}{\left(\frac{\text { Rentang Waktu(menit })}{60 \text { (detik) }}\right)}$

\subsection{Pengujian Gelombang $I 2 C$}

Pengujian gelombang I2C dilakukan dengan cara mendeteksi berapa nilai byte yang dikirim dan byte yang diterima berdasarkan address register pada modul yang di deteksi. Modul yang digunakan sebagai sample adalah MAX30100 dengan read address 0xAF dan write address 0xAE. Hasil gelombang seperti Gambar 7 berikut.

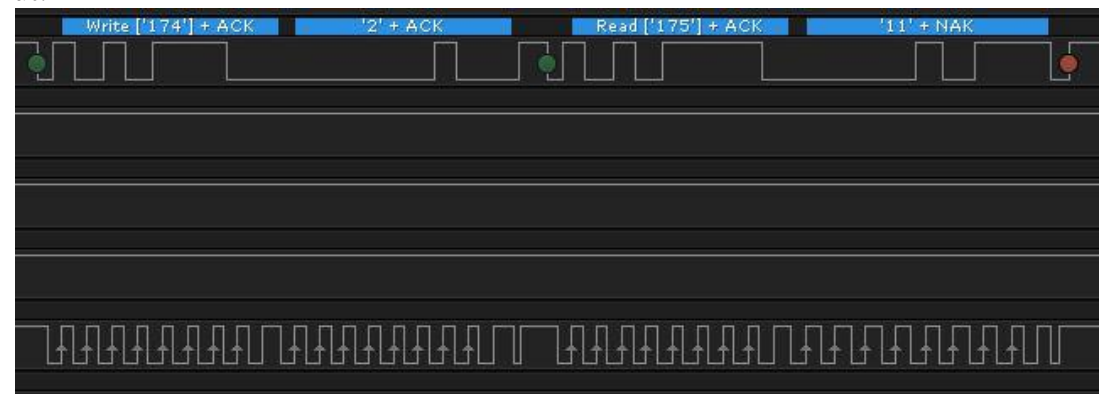

Gambar 7. Bentuk Gelombang I2C MAX30100

Dari hasil pendeteksian gelombang diatas bit 1 melakukan penulisan dan ACK dengan alamat 0xAE (174 dalam desimal) dilanjutkan pada bit 2 menulis data byte 0x02 dan ACK diteruskan dengan menunggu 2 byte lalu melakukan pembacaan dengan alamat 0xAF (175 dalam desimal) dengan pembacaan 0x0B dan diikuti dengan NAK yang menandakan berakhirnya komunikasi I2C. 


\section{HASIL DAN PEMBAHASAN}

Setelah melakukan pengujian rangkaian dan perancangan alat maka diperoleh hasil berupa rancang bangun pengatur infus berbasis mikrokontroller seperti Gambar 8 dan Gambar 9 Berikut.

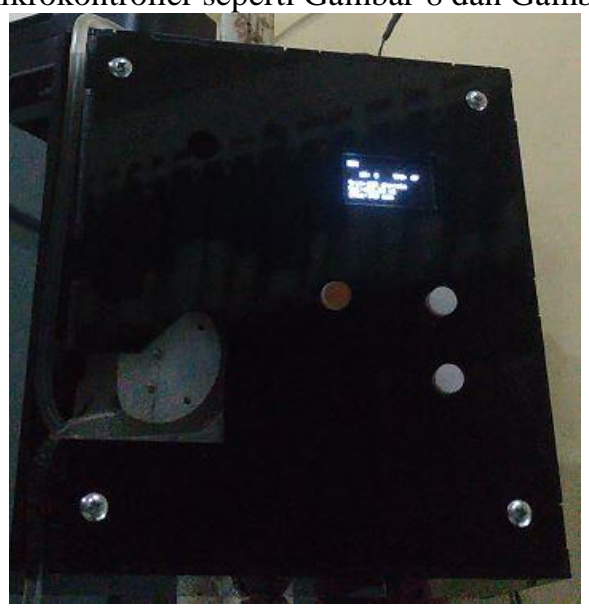

Gambar 8. Sistem Pengatur Tetesan Infus

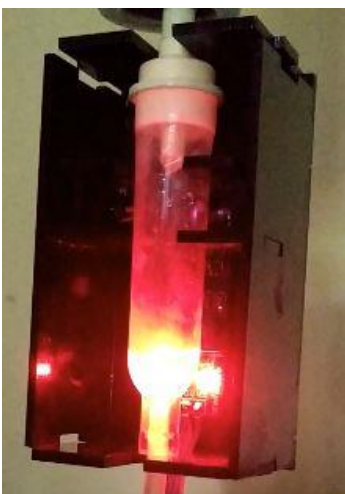

Gambar 9. Tempat Sensor Tetesan

\subsection{Pengujian Pengukuran Detak Jantung}

Pengujian dilakukan dengan menggunakan 4 subjek usia sekitar 20 - 25 dengan rentang pengukuran 30 detik dengan 10 data per subjek dilakukan di sekitaran Fakultas Teknik dan Sains, Universitas Muhammadiyah Purwokerto.dengan cara membandingkan pengukuran secara manual dan menggunakan alat secara bersamaan. Setelah dilakukan pengujian didapatkan hasil seperti Gambar 10 dan Gambar 11 berikut.

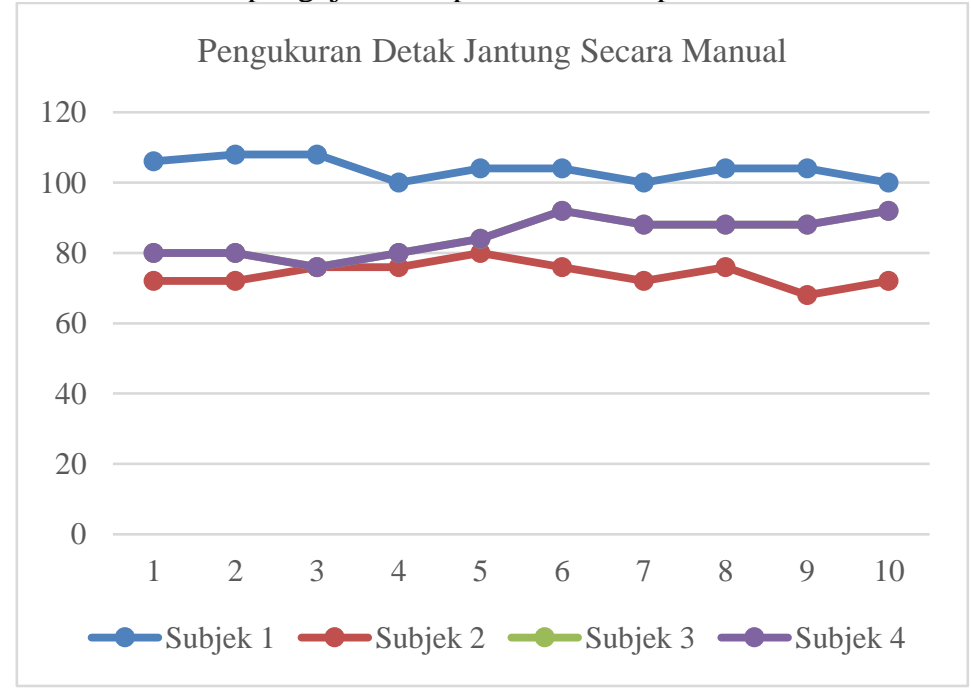

Gambar 10. Grafik Pengukuran Detak Jantung Secara Manual 


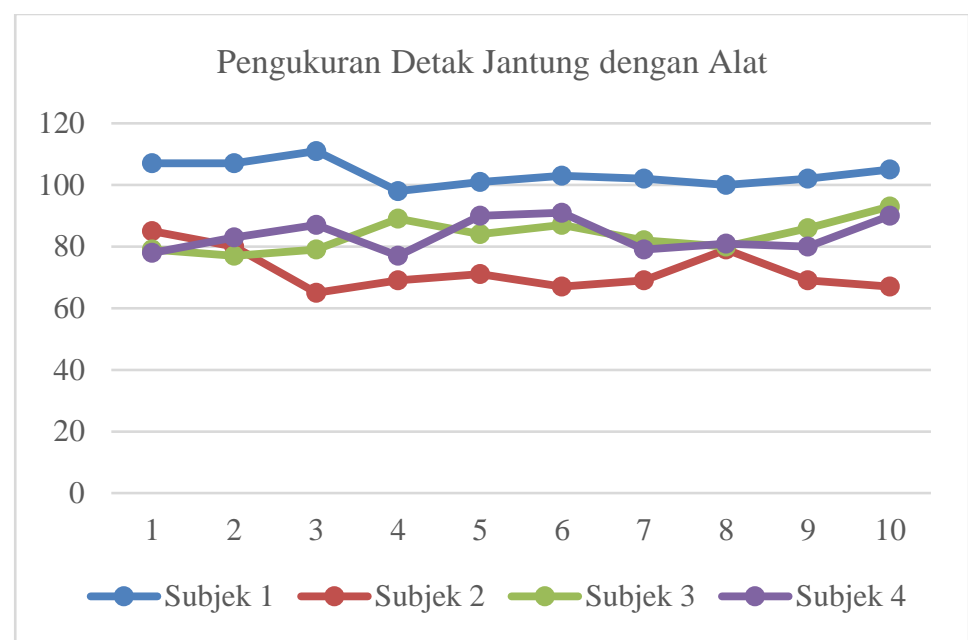

Gambar 11. Grafik Pengukuran Detak Jantung dengan Alat

Dari data pada Gambar 10 dan Gambar 11 terdapat rata - rata error yang melebihi 10\% pada subjek 2 hal ini terjadi karena saat memegang sensor detak jantung kurang tepat sehingga pada saat mendeteksi menjadi kurang maksimal sedangkang rata - rata error pada subjek lain antara $2 \%$ hingga $4 \%$ karena dalam memegang sensor tepat atau bisa dikatakan pas. Sehingga jika dihitung rata - rata error keseluruhan menjadi $5.57 \%$.

\subsection{Pengujian Pengaturan Tetesan}

Pengujian pengaturan tetesan infus dilakukan dengan cara pengaturan secara manual dengan pengaturan menggunakan alat, acuan untuk pengaturan secara manual dan dengan alat diberikan 10 sample tetesan dengan 3 data pengaturan setiap sample. Setelah dilakukan pengujian maka didapatkan hasil seperti Gambar 12 dan Gambar 13 berikut.

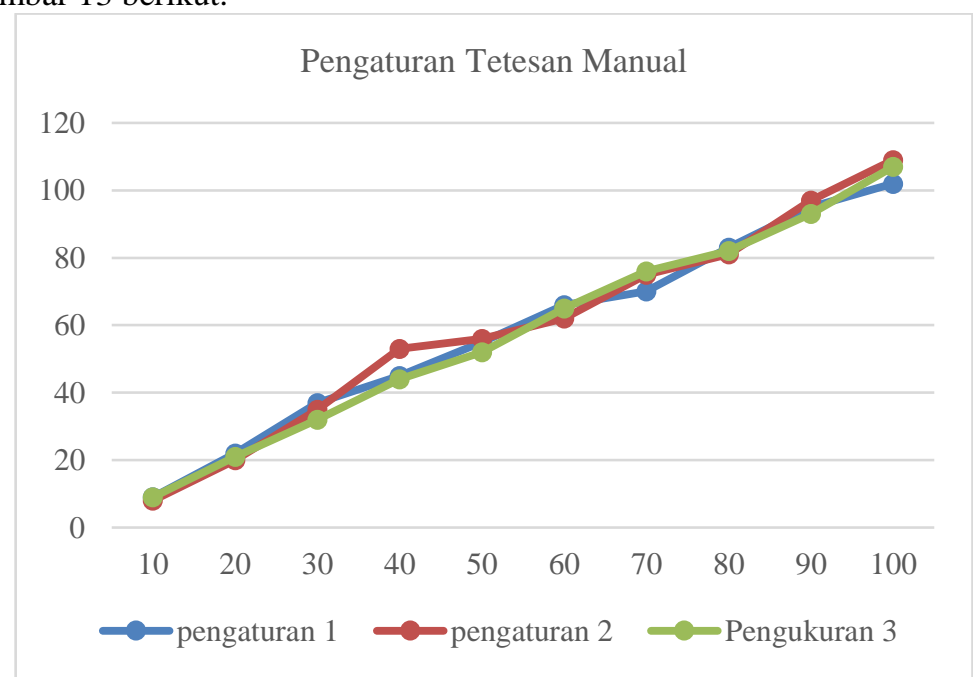

Gambar 12. Grafik Pengaturan Tetesan Secara Manual 


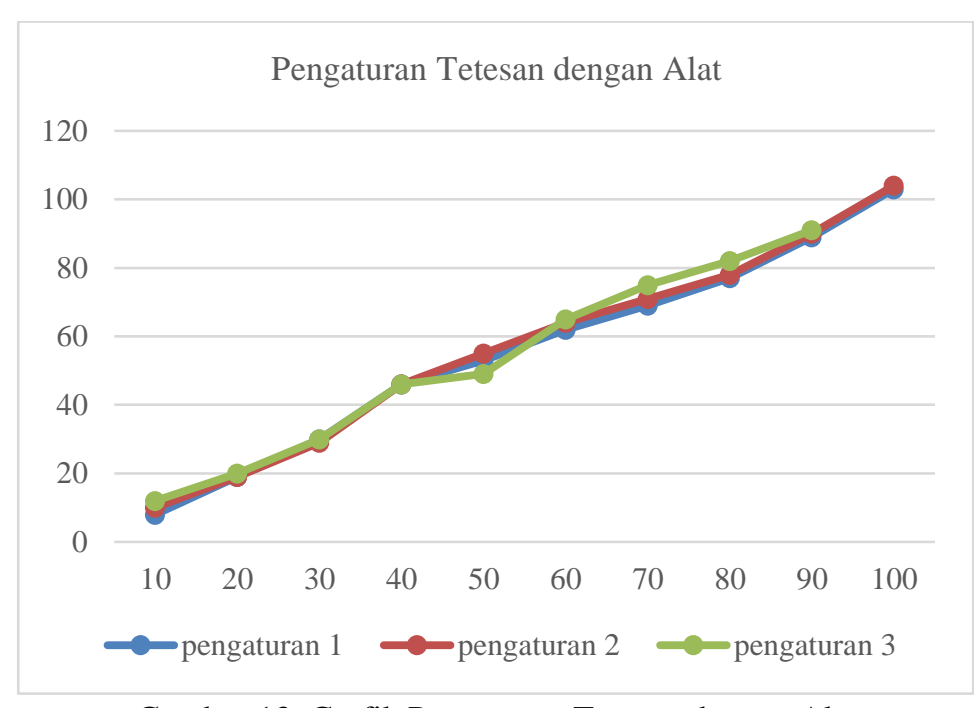

Gambar 13. Grafik Pengaturan Tetesan dengan Alat

Dari data pengujian pada Gambar 12 dan Gambar 13 diatas pada pengujian pengaturan infus secara manual terdapat error yang cukup besar $20 \%$ pada sample 10 dan 30 tetesan hal ini dikarenakan dalam pengaturan secara manual memiliki waktu yang cukup lama sekitar 3 - 7 menit untuk mengatur tetesan sesuai dengan yang diinginkan, dari pengujian secara manual didapatkan error total 7,891\% dan pada pengujian pengaturan tetesan dengan alat terdapat error yang cukup besar pada sample 10 tetesan sekitar $20 \%$ hal ini dikarenakan nilai sample yang terlalu kecil sehingga jika selisih 2 angka saja maka nilai errornya akan cukup besar, pada pengujian pengaturan tetesan ini memiliki error sebesar 5,586\%.

\subsection{Pengujian Kirim dan Terima Data}

Pengujian kirim dan terima data dilakukan untuk mengetahui apakah data benar terkirim atau tidak dan mengecek apakah ada data yang hilang ketika dibaca di aplikasi android. Pengujian ini dilakukan dengan cara melihat dari aplikasi arduino yang di pasang serial data pada perangkat dengan baud rate 115200 dan aplikasi android yang datanya didapat ketika android masih terhubung pada laptop, hasil pengujian seperti pada tabel 2 berikut.

Tabel 2. Pengujian Kirim dan Terima Data

\begin{tabular}{cccc}
\hline Pengukuran & Kirim Data & Terima Data & Delay (ms) \\
\hline 1 & $10: 27: 55: 012$ & $10: 27: 55: 071$ & 59 \\
2 & $10: 29: 16: 550$ & $10: 29: 16: 583$ & 33 \\
3 & $10: 30: 46: 832$ & $10: 30: 46: 889$ & 57 \\
4 & $10: 31: 55: 152$ & $10: 31: 55: 203$ & 51 \\
5 & $10: 32: 46: 155$ & $10: 32: 46: 253$ & 98 \\
\hline \multicolumn{5}{c}{ Rata - rata Delay (ms) }
\end{tabular}

Setelah dilakukan pengujian kirim dan terima data antara perangkat dan aplikasi android di dapatkan hasil yang cukup cepat dalam menerima maupun mengirim yang memiliki rata - rata delay 59,6 microsecond, yang artinya dalam pengiriman maupun penerimaan data hampir realtime tetapi hal ini juga di pengaruhi oleh konektivitas internet yang ada.

\section{KESIMPULAN}

Dari hasil penelitian yang telah dilakukan pada pengatur tetesan infus maka diperoleh kesimpulan bahwa sistem pengatur tetesan infus berbasis mikrokontroller telah berhasil dibuat dengan memaksimalkan teknologi yang ada dengan dana seminimal mungkin dan telah dilakukannya pengujian dengan besar kesalahan pengatur tetesan rata - rata 5,586\% dan besar kesalahan deteksi detak jantung 5,57\%. Sistem yang dibuat telah berhasil memonitoring dan mengendalikan atau mengubah nilai tetesan dengan menggunakan aplikasi android. Faktor selang sangat berpengaruh terhadap pengaturan tetesan karena jika ada perubahan posisi sedikit saja dapat merubah nilai dari tetesan dan nilai tersebut relatif akan jauh dari nilai yang diharapkan 


\section{DAFTAR PUSTAKA}

[1] Gayatri, D., \& Handayani, H. (2008). Hubungan jarak pemasangan terapi intravena dari persendian terhadap waktu terjadinya flebitis. Jurnal Keperawatan Indonesia, 11 (1), 1-5.

[2] Alexander, M, Corrigan, A, Gorski, L, Hankins, J., \& Perucca, R. (2010). Infusion nursing society, Infusion nursing: An evidence-based approach (3rd Ed.). St. Louis: Dauders Elsevier.

[3] Rothschild JM, Keohane CA, Cook EF, et al.A controlled trial of smart infusion pumps to improve medication safety in critically ill patients. Crit Care Med 2005; Vol. 33 No.3: 533-40.

[4] Choi, Geun Joo, Yoon, Il Jae, Lee, Oh Haeng \& Kang, Hyun 2015. 'Accuracy of an Automatic Infusion Controller(AutoClamp) for Intravenous Fluid Administration'. The Open Anesthesiology Journal. Vol 9. hh 23-28

[5] Padmaja,K \& Kalgal, A 2013. 'Smart Infusion Pump: A boon to the Health Care Industry'. IJETT.Vol 4. hh 25702573

[6] Falat, Jati.(2006). Realisasi Monitoring Level Cairan Infus Pada Pasien Rawat Inap Berbasis PC. Bandung : Politeknik Negeri Bandung.

[7] Alexander, M, Corrigan, A, Gorski, L, Hankins, J., \& Perucca, R. (2010). Infusion nursing society, Infusion nursing: An evidence-based approach (3rd Ed.). St. Louis: Dauders Elsevier.

[8] A.Azis Alimul Hidayat \& Musrifatul Uliyah. ( 2012 ). Buku Ajar Kebutuhan Dasar Manusia. Surabaya : Health Books Publishing

[9] Smeltzer, S.C. \& Bare, B.G. (2013). Buku Ajar Keperawatan Medikal Bedah Brunner \& Suddarth, edisi 8. Jakarta : EGC.

[10] Saputro, Yusuf Eko. (2018). Alat Pengatur Tetesan Air Infus Sesuai Kebutuhan Pasien. Fakultas Teknik Elektro. Universitas Muhammadiyah Ponorogo. Ponorogo.

[11] Muslim, Abdy. 2010. Monitoring Cairan Infus Menggunakan Modul Radio Frekuensi YS 1020 UB Dengan Frekuensi 433 MHZ. Jurusan Teknik Elektro, Fakultas Teknik Universitas Diponegoro. Diakses tanggal 10 Juni 2020 . 